\title{
Deep danger: intra-specific predation risk influences habitat use and aggregation formation of juvenile lemon sharks Negaprion brevirostris
}

\author{
Tristan L. Guttridge ${ }^{1,2,5, *}$, Samuel H. Gruber ${ }^{2,3}$, Bryan R. Franks ${ }^{2,4}$, Steven T. Kessel ${ }^{2,5}$, \\ Katie S. Gledhill ${ }^{2}$, Jen Uphill ${ }^{6}$, Jens Krause ${ }^{7,8}$, David W. Sims ${ }^{9,10}$ \\ ${ }^{1}$ Institute for Integrative and Comparative Biology, University of Leeds, L.C. Miall Building, Leeds LS2 9JT, UK \\ ${ }^{2}$ Bimini Biological Field Station, 15 Elizabeth Drive, South Bimini, Bahamas \\ ${ }^{3}$ Division of Marine Biology and Fisheries, Rosenstiel School of Marine and Atmospheric Science, \\ 4600 Rickenbacker Causeway, Miami, Florida 33149, USA \\ ${ }^{4}$ Department of Biology, Rollins College, Winter Park Florida 32789, USA \\ ${ }^{5}$ School of Earth and Ocean Sciences, Cardiff University, Cardiff CF10 3XQ, UK \\ ${ }^{6}$ Flinders University, Stuart Drive, Bedford Park, South Australia 5042, Australia \\ ${ }^{7}$ Department of Biology and Ecology of Fishes, Leibniz-Institute of Freshwater Ecology and Inland Fisheries, Müggelseedamm 310, \\ 12587 Berlin, Germany \\ ${ }^{8}$ Department of Biology and Ecology of Fishes, Humboldt-University of Berlin, Philippstrasse 13, 10115 Berlin, Germany \\ ${ }^{9}$ Marine Biological Association of the United Kingdom, The Laboratory, Citadel Hill, Plymouth PL1 2PB, UK \\ ${ }^{10}$ Marine Biology and Ecology Research Centre, School of Marine Science and Engineering, University of Plymouth, \\ Drake Circus, Plymouth PL4 8AA, UK
}

\begin{abstract}
Non-consumptive or risk effects imposed by predators can influence prey behaviour over different spatio-temporal scales. Prey vulnerability to predation can also be dependent on abiotic conditions, such as tidal height. We conducted direct field observations of juvenile lemon sharks Negaprion brevirostris in a tidally influenced mangrove-inlet. We also used acoustic tracking to determine the movement patterns of juvenile lemon sharks and their predators (sub-adult lemon sharks) across the tidal cycle. Results showed that greater numbers of juvenile lemon sharks used the mangrove-inlet for longer time periods at deeper and warmer high tide depths. This coincided with an increased presence of potential predators (sub-adult lemon sharks) in the surrounding areas. Furthermore, in accordance with body-size dependent anti-predatory investment, smaller juvenile lemon sharks visited the mangrove inlet more often, spent longer there and left latest on average. Our acoustic tracking data also revealed a tidally-influenced pattern, with both juvenile and sub-adult lemon sharks detected at locations inshore over the high tide and offshore during the low tide. We concluded that the mangrove lake served as a 'refuge' for juvenile lemon sharks over the high tide, providing safe habitat when inshore areas become accessible to large predators, such as sub-adult lemon sharks. We suggest that these decisions are updated through ontogeny and also with daily fluctuations in abiotic factors, such as water depth. This study provides evidence for how intra-specific predator-prey interactions in a top predator species influence juvenile habitat selection, with potential implications for population structure and regulation.
\end{abstract}

KEY WORDS: Apex predator $\cdot$ Cannibalism $\cdot$ Elasmobranchs $\cdot$ Refuge use $\cdot$ Risk effects Resale or republication not permitted without written consent of the publisher

\section{INTRODUCTION}

Predators can influence prey communities through direct predation and also through the costs of antipredatory behavioural responses or risk effects
(Abrams 1995, Lima 1998, Werner \& Peacor 2006, Creel \& Christianson 2008). The interactions between predators and prey are dynamic because the risk of being preyed upon changes through time and space (Lima \& Dill 1990). Studies from a variety of 
taxa have demonstrated that responses to predation risk can result in changes in morphology (Nilsson et al. 1995, Van Buskirk \& Arioli 2002) and behaviour (Creel \& Christianson 2008, Lima 2009).

In recent years the non-consumptive effects of predators have also been considered for marine communities (Dill et al. 2003, Trussell et al. 2004, Wirsing et al. 2008, Heithaus et al. 2008). Most sharks are regarded as important top predators in marine ecosystems, but they are also abundant at the mesopredator level, through a high diversity of small-bodied sharks and juvenile or immature individuals of larger species (Ferretti et al. 2010). Intra-specific predation or cannibalism of juveniles by larger conspecifics has been documented in a number of species, including bull Carcharhinus leucas, lemon Negaprion brevirostris and great hammerhead Sphyrna mokarran sharks (Vorenberg 1962, Snelson et al. 1984, Morrissey \& Gruber 1993). In other taxa, where cannibals and victims are in different year classes or life stages, dominant cohorts of cannibals can regulate recruitment in populations (Benoit et al. 1998, Wissinger et al. 2010). Studies investigating habitat selection for juvenile or neonatal Carcharhiniform species have previously attributed ontogenetic differences in habitat use to intra-specific predation risk (Pillans \& Franklin 2004, Wetherbee et al. 2007). However, few studies have explored the possibility that predation risk affects fine-scale space use decisions of juvenile and neonatal sharks (Heithaus 2007). Most studies to date rely on average location over long time intervals as a proxy for individual habitat use, which makes exploring questions about the mechanisms driving habitat selection and behavioural decisions made over short temporal and spatial scales difficult (Heupel \& Simpfendorfer 2005, Heithaus 2007, Knip et al. 2010).

Animals clearly make decisions about habitat use by assessing the abiotic conditions specific to their environment, for example water temperature, depth and salinity (Andrewartha \& Birch 1954, Jackson et al. 2001). These factors can be used as indicators for locating quality foraging patches, as well as safe locations to avoid predators. In coastal marine habitats, such as mangroves or estuaries, water depth can change significantly over the tidal cycle (Sheaves 2005). The range of shallow habitats available to large-bodied predators therefore increases over the high tide, so small-bodied prey must go to even shallower locations or use different habitats that remain relatively inaccessible to avoid these predators. For example, sea snakes Hydrophis elegans avoid predation from tiger sharks Galeocerdo cuvier by selecting seagrass refuge habitats at high tide when the presence of predators is elevated (Kerford et al. 2008). However, movements to high tide habitats can also be driven by acquisition of resources that are not available at low tides. Dugong Dugong dugon movements to shallow intertidal zones at high tide were thought to be influenced by higher seagrass patch profitability (Sheppard et al. 2009). The decision about when or for how long to use a refuge area or food patch can also be influenced by individual characteristics, such as body size. Across many animal taxa the dramatic decline in risk of predation as body size increases is well documented (Werner \& Gilliam 1984). For gape-limited predators, such as teleost fishes, this pattern is particularly strong (Brose et al. 2006), and evidence from a number of marine fishes indicates that anti-predator behaviour (use of shallow water refuges) can be size-dependent (Halpin 2000, Linehan et al. 2001, Manderson et al. 2004). However, the influence of the tidal cycle and body size on large marine predator-prey interactions remains largely unexplored.

The lemon shark Negaprion brevirostris is a largebodied coastal species that occurs in the Eastern Pacific and Western and Eastern Atlantic (Compagno 1984). Adult lemon sharks are highly mobile, with females known to exhibit seasonal fidelity to particular nursery areas for parturition (Feldheim et al. 2002). In contrast, newborn and small juvenile lemon sharks typically reside in shallow habitats in their natal nursery area (Morrissey \& Gruber 1993, Wetherbee et al. 2007, Garla et al. 2009). In our study system, Bimini (Bahamas), a subtropical island cluster, juvenile lemon sharks $<1 \mathrm{~m}$ total length (TL) remain within their natal nursery area, utilising habitats close to shore presumably to avoid larger predatory sharks and exploit abundant prey communities (Morrissey \& Gruber 1993, Franks 2007, Newman et al. 2010). As individuals approach $1 \mathrm{~m}$ TL they expand their home-ranges, moving further offshore into deeper habitats seeking larger prey items (Sundström et al. 2001, Newman et al. 2010). Upon reaching sexual maturity ( 2.3 to $2.4 \mathrm{~m} \mathrm{TL}$ ) they are thought to disperse to reproduce (Chapman et al. 2009). Lemon sharks are recognised to be cannibalistic, and sub-adults (>1.3 m TL) in Bimini have been observed to prey on juveniles (<1 m TL; Vorenberg 1962, Morrissey \& Gruber 1993). Juvenile lemon sharks are therefore likely to resemble other marine fishes and invest in anti-predatory behaviour in order to manage this risk. In Bimini, large numbers (ca. 20 to 30 ) of juvenile lemon sharks ( $<1.1 \mathrm{~m}$ TL) have been documented to use mangrove-inlets and channels 
that are only accessible between mid-tides over the high (Franks 2007, Guttridge et al. 2011). At one of these sites (Aya's Spot) sharks have been observed daily to interact in social groups following and resting in shallow water ( 0.2 to $0.9 \mathrm{~m}$ depth), often within mangrove edge habitat (Guttridge et al. 2011). A shallow channel entrance, interspersed with mangrove prop roots, precludes access to larger predatory sharks, such as sub-adult conspecifics (>1.3 m). This site likely provides a physical refuge for juvenile lemon sharks during the high tide when predators are able to access habitats closer to shore.

In this study, we conducted direct observations of juvenile lemon sharks in Aya's Spot (AS) mangroveinlet and used acoustic tracking to determine the movement patterns of juvenile lemon sharks and their predators (sub-adult lemon sharks) across the tidal cycle. Under the assumption that predation risk (presence of sub-adult predators) increases over the high tide and smaller juvenile lemon sharks are at greatest risk, this hypothesis predicts that (1) juvenile lemon sharks should select high tide habitats, such as $\mathrm{AS}$, that provide the lowest probability of encountering a predator, (2) relative use (number of sharks and duration of visit) of AS should be greatest at deeper high tide depths, (3) smaller juvenile lemon sharks should spend longer in AS, depart later and return on a greater number of days, and (4) the number of predators detected in nearshore habitats should be at its highest over the high tide. The use of AS could also be influenced by other factors, such as water temperature or food availability. Physiological functions are known to be directly affected by changes in temperature (Schmidt-Nielsen 1990), and habitat selection for a number of shark species indicates a thermoregulatory function (Economakis \& Lobel 1998, Hight \& Lowe 2007). For the sharks in this study, utilising warmer water should increase rates of metabolism and digestion, which in turn could lead to an increase in growth rate if coupled with increased food intake. Under this assumption we should find that juvenile lemon sharks use AS at warmer high tide depths and for longer time periods.

\section{MATERIALS AND METHODS}

\section{Study site}

The study was conducted at Bimini, Bahamas $\left(25^{\circ}\right.$ $44^{\prime} \mathrm{N}, 79^{\circ} 16^{\prime} \mathrm{W}$ ), a subtropical cluster of islands approximately $85 \mathrm{~km}$ east of Miami, Florida, USA. Research was focused on the south east coast of the
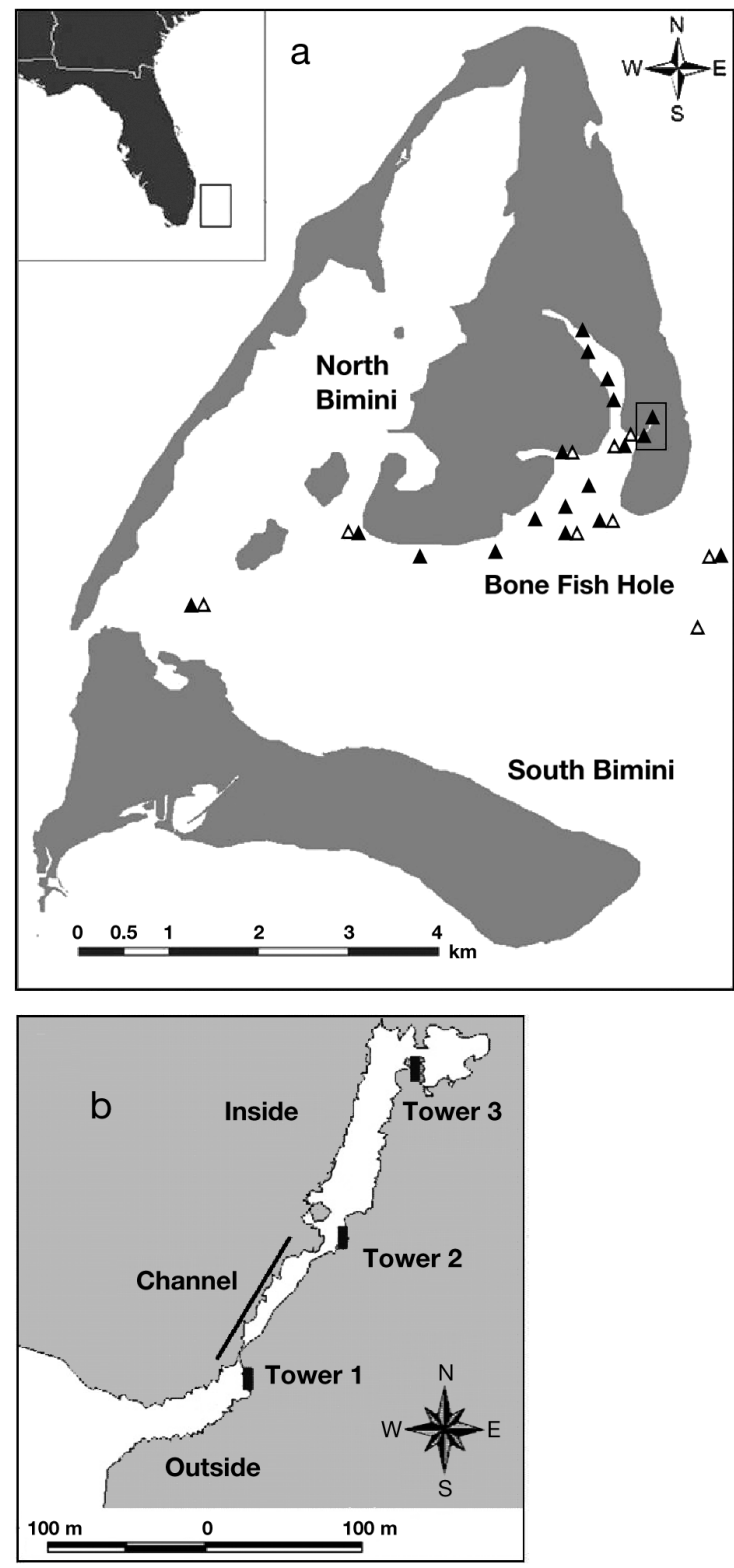

Fig. 1. (a) Study site in Bimini Islands $\left(25^{\circ} 44^{\prime} \mathrm{N}, 79^{\circ} 16^{\prime} \mathrm{W}\right)$ showing locations of Bone Fish Hole nursery area, Aya's Spot and the underwater acoustic receivers (URs). (ム) UR locations for juvenile lemon shark study (September to November 2008). ( $\Delta$ ) UR locations for the sub-adult lemon shark study (January 2007 to November 2008). Black rectangle marks Aya's Spot. (b) Aya's Spot showing tower positions and outside and inside refuge areas

North Island in an area known as Aya's Spot (AS; Fig. 1). This area has been the location for a series of studies investigating aspects of juvenile lemon shark behavioural ecology. The sharks use the area daily and are regularly observed to aggregate at and around the high tide (Guttridge et al. 2010, 2011). 


\section{Direct observations}

Three temporary observation towers $4 \mathrm{~m}$ in height were constructed and positioned to provide almost complete visual coverage of AS (Fig. 1b). Over a $2 \mathrm{yr}$ period, a total of 58 juvenile lemon sharks ( $\mathrm{n}=$ 25 females, $\mathrm{n}=33$ males; $\mathrm{TL}=79 \pm 12.3 \mathrm{~cm}$, mean \pm $\mathrm{SD}$ ) were caught every 3 to 4 mo (some repeatedly) through seine and gill netting (Guttridge et al. 2011). Briefly, all sharks were sexed, measured (pre-caudal, total length), tagged with a passive integrated transponder (PIT, Destron Fearing ${ }^{\circledR}$ ) and colour-code tagged through the first dorsal fin (T-bar anchor tag, Floy Tag $^{\circledR}$ ) to enable individual identification using mono-, bi- or tri-coloured tags. Observations on $73 \mathrm{~d}$ were conducted simultaneously from all 3 towers between May 2006 and December 2007. These days were selected based on the following criteria: (1) high tide, 10:00 to $16: 00 \mathrm{~h}$, and (2) wind speed $<20 \mathrm{~km} \mathrm{~h}^{-1}$. This was to ensure that water surface and light levels did not affect clear identification of sharks. Preliminary observations over the full tidal cycle revealed that no sharks used the area over the low tide period because AS regularly dried out, thus preventing access (Guttridge et al. 2011). Observers arrived at mid-tide before the sharks and left once the last shark had departed the area, usually 6 to $8 \mathrm{~h}$ later. The following information was collected during observation days: (1) Shark presence, including time and identity of first shark sighting, which was confirmed through correct identification of colour code tags, (2) Scan sampling every 2 min including time spent by, and identity of, sharks in front of tower, and (3) Inside section use including time spent inside section and identity of sharks that entered or exited AS's channel (Fig. 1b).

Observations were divided into 3 time periods: (1) May to December 2006, which included 35 observation days; (2) January to May 2007, 22 d; and (3) May to December 2007, $16 \mathrm{~d}$. Time periods were used to ensure that neonate sharks were included in the analysis post June 2007 and to control for the effect of shark growth on the observed patterns (i.e. shark body length was updated for each time period). Water temperature and depth were monitored at 10 min intervals throughout the observation days from Tower 1: depth from a $1.5 \mathrm{~m}$ pole (0.01 m increments) and temperature using a data logger (Maxim, Thermochron i-buttons $\left.{ }^{\circledR}\right)$ accurate to the nearest $1^{\circ} \mathrm{C}$. High tide depth ranged from 0.24 to $0.84 \mathrm{~m}(0.53 \pm$ $0.12 \mathrm{~m}$ ) and high tide temperatures ranged from 18 to $32^{\circ} \mathrm{C}\left(26 \pm 4^{\circ} \mathrm{C}\right)$.

\section{Movement tracking}

Shark capture and instrumentation. From October 2006 to October 2008, 24 sub-adult and adult lemon sharks $(\mathrm{n}=9$ females, $\mathrm{n}=15$ males; $\mathrm{TL}=1.77 \pm$ $0.33 \mathrm{~m}$, Table 1) were captured in North Bimini using long-line and rod and reel techniques (Kessel 2010). After capture, all sharks were sexed, measured (precaudal, TL), tagged with a PIT and external National Marine Fisheries Service (NMFS) m-type dart tag (Kohler \& Turner 2001). Acoustic transmitters (Sonotronics ${ }^{\circledR}$ CHP-87-L, battery life $18 \mathrm{mo}$ ) were placed both externally and internally (for description see Sundström et al. 2001, Wetherbee et al. 2007).

Between 30 September and 5 October 2008, 13 juvenile lemon sharks $(n=6$ females, $n=7$ males; $\mathrm{TL}=87 \pm 13 \mathrm{~cm}$ ) were caught by seine and gill netting in the Bone Fish Hole (BFH) nursery area (Table 2). They were treated as above (excluding the dart tag), and an acoustic transmitter (Sonotronics ${ }^{\circledR}$ IBT-2, battery life $60 \mathrm{~d}$ ) was implanted intra-abdominally (Guttridge et al. 2010). All transmitter-carrying sharks swam off vigorously when released and were later detected on automated receivers, confirming that all survived capture and tagging. Furthermore, recaptured individuals showed healed wounds and growth rates comparable to non-transmitter carrying sharks (T. L. Guttridge pers. obs.).

Acoustic monitoring. The areas occupied by subadult lemon sharks were monitored from January 2007 to November 2008 with 9 submersible underwater receivers (Sonotronics ${ }^{\circledR}$, SUR-1). An additional 9 underwater receivers (UR) were placed during October and November 2008, providing coverage of the BFH nursery area (Fig. 1a). Each UR recorded the time, date and identity of the acoustic tag fitted to a shark that swam within range. Detection ranges of individual URs were dependent on location and tidal state, varying from a maximum of $300 \mathrm{~m}$ radius at high tide to a minimum of $50 \mathrm{~m}$ at low tide (Guttridge et al. 2010). URs were housed in a PVC pipe with a concrete base that was buried $\sim 0.30 \mathrm{~m}$ into the substrate, ensuring that all URs were at the same level in the water column and secured in position. They were retrieved to download data and returned to the recording location in the same $24 \mathrm{~h}$ period once per month. Data were filtered to remove spurious detections, which were defined as any single transmitter detections occurring alone within a $24 \mathrm{~h}$ period. All other detections were treated as genuine and were assigned a tidal phase. High and low tide times were obtained from NOAA (National Oceanic and Atmospheric Administration), 
Table 1. Negaprion brevirostris. Sub-adult (S) and adult lemon sharks (A) captured to attach acoustic transmitters in Bimini, Bahamas, from October 2006 to October 2008. M: male, F: female

\begin{tabular}{|c|c|c|c|c|c|c|c|c|}
\hline $\begin{array}{l}\text { Shark } \\
\text { ID no. }\end{array}$ & Stage & $\begin{array}{l}\text { Date tagged } \\
(\mathrm{d} / \mathrm{mo} / \mathrm{yr})\end{array}$ & $\begin{array}{l}\text { Dates monitored } \\
(\mathrm{d} / \mathrm{mo} / \mathrm{yr})\end{array}$ & $\begin{array}{l}\text { No. of days } \\
\text { monitored }\end{array}$ & $\begin{array}{c}\text { No. of days } \\
\text { with detections } \\
\text { (\% days monitored) }\end{array}$ & $\begin{array}{l}\text { Total length } \\
(\mathrm{cm})\end{array}$ & Sex & $\begin{array}{c}\text { No. of } \\
\text { detections }\end{array}$ \\
\hline 3775 & $\mathrm{~S}$ & $31 / 10 / 2006$ & $23 / 01 / 2007-03 / 07 / 2007$ & 161 & $17(11)$ & 145 & $\mathrm{~F}$ & 113 \\
\hline 3774 & $\mathrm{~S}$ & $11 / 12 / 2006$ & $23 / 01 / 2007-08 / 08 / 2007$ & 197 & $84(43)$ & 163 & $\mathrm{M}$ & 470 \\
\hline 4467 & $\mathrm{~S}$ & 03/01/2007 & $23 / 01 / 2007-05 / 07 / 2007$ & 163 & $70(43)$ & 157 & $\mathrm{~F}$ & 526 \\
\hline 4568 & $\mathrm{~S}$ & $31 / 01 / 2007$ & $31 / 01 / 2007-29 / 09 / 2007$ & 241 & $42(17)$ & 196 & $\mathrm{~F}$ & 262 \\
\hline 3387 & $\mathrm{~S}$ & $20 / 03 / 2007$ & $20 / 03 / 2007-29 / 04 / 2007$ & 40 & $1(3)$ & 168 & M & 18 \\
\hline 6678 & $\mathrm{~S}$ & $05 / 04 / 2007$ & 05/04/2007-28/07/2007 & 114 & $19(17)$ & 171 & M & 70 \\
\hline 5578 & $\mathrm{~S}$ & $13 / 04 / 2007$ & $13 / 04 / 2007-06 / 08 / 2007$ & 115 & $25(22)$ & 190 & M & 51 \\
\hline 678 & $\mathrm{~S}$ & $17 / 04 / 2007$ & $17 / 04 / 2007-26 / 07 / 2007$ & 100 & $15(15)$ & 175 & $\mathrm{~F}$ & 33 \\
\hline 5577 & $\mathrm{~S}$ & $17 / 04 / 2007$ & $17 / 04 / 2007-01 / 09 / 2007$ & 137 & $25(18)$ & 164 & $\mathrm{~F}$ & 49 \\
\hline 3386 & $\mathrm{~S}$ & $20 / 04 / 2007$ & $20 / 04 / 2007-02 / 11 / 2007$ & 196 & $88(45)$ & 167 & M & 561 \\
\hline 3475 & $\mathrm{~S}$ & $20 / 04 / 2007$ & $20 / 04 / 2007-21 / 02 / 2008$ & 307 & $11(4)$ & 205 & M & 72 \\
\hline 3558 & $\mathrm{~S}$ & 06/06/2007 & 06/06/2007-03/10/2007 & 119 & $55(46)$ & 136 & $\mathrm{~F}$ & 667 \\
\hline 446 & $\mathrm{~S}$ & $14 / 06 / 2007$ & $14 / 06 / 2007-18 / 10 / 2007$ & 126 & $50(40)$ & 180 & M & 488 \\
\hline 3354 & $\mathrm{~S}$ & $14 / 06 / 2007$ & $14 / 06 / 2007-26 / 06 / 2007$ & 12 & $2(17)$ & 190 & M & 8 \\
\hline 376 & $\mathrm{~S}$ & $22 / 07 / 2007$ & $22 / 07 / 2007-25 / 10 / 2007$ & 95 & $81(85)$ & 147 & M & 591 \\
\hline 3366 & $\mathrm{~S}$ & $04 / 10 / 2007$ & $04 / 10 / 2007-05 / 08 / 2008$ & 306 & $113(37)$ & 141 & M & 736 \\
\hline 3455 & $\mathrm{~S}$ & $11 / 12 / 2007$ & $11 / 12 / 2007-20 / 12 / 2007$ & 9 & $7(78)$ & 178 & M & 95 \\
\hline 3456 & $\mathrm{~S}$ & $11 / 12 / 2007$ & $11 / 12 / 2007-10 / 05 / 2008$ & 151 & $32(21)$ & 210 & M & 222 \\
\hline 667 & $\mathrm{~A}$ & $21 / 04 / 2008$ & $21 / 04 / 2008-22 / 04 / 2008$ & 1 & $1(100)$ & 268 & $\mathrm{~F}$ & 4 \\
\hline 445 & A & 08/05/2008 & 08/05/2008-12/11/2008 & 188 & $17(9)$ & 243 & $\mathrm{~F}$ & 66 \\
\hline 3347 & $\mathrm{~S}$ & $15 / 05 / 2008$ & $15 / 05 / 2008-18 / 08 / 2008$ & 95 & $13(14)$ & 145 & M & 185 \\
\hline 3346 & $\mathrm{~S}$ & 01/08/2008 & 01/08/2008-07/08/2008 & 7 & $5(71)$ & 178 & $\mathrm{~F}$ & 94 \\
\hline 466 & $\mathrm{~S}$ & $03 / 10 / 2008$ & 03/10/2008-13/11/2008 & 41 & $18(44)$ & 210 & $\mathrm{M}$ & 87 \\
\hline 334 & $\mathrm{~S}$ & $05 / 10 / 2008$ & $05 / 10 / 2008-15 / 11 / 2008$ & 41 & 39 (95) & 130 & M & 536 \\
\hline Total & & & & & & & & 6004 \\
\hline
\end{tabular}

Table 2. Negaprion brevirostris. Juvenile lemon sharks captured and fitted with transmitters in Bimini, Bahamas, during September and October 2008. M: male, F: female, na: not applicable

\begin{tabular}{|c|c|c|c|c|c|c|c|}
\hline $\begin{array}{l}\text { Shark ID no. } \\
\text { (Transmitter no.) }\end{array}$ & $\begin{array}{l}\text { Date tagged } \\
(\mathrm{d} / \mathrm{mo} / \mathrm{yr})\end{array}$ & $\begin{array}{l}\text { Dates monitored } \\
\qquad(\mathrm{d} / \mathrm{mo} / \mathrm{yr})\end{array}$ & $\begin{array}{c}\text { No. of days } \\
\text { monitored }\end{array}$ & $\begin{array}{c}\text { No. of days } \\
\text { with detections } \\
\text { (\% days monitored) }\end{array}$ & $\begin{array}{l}\text { Total length } \\
(\mathrm{cm})\end{array}$ & Sex & $\begin{array}{c}\text { No. of } \\
\text { detections }\end{array}$ \\
\hline $366(3)$ & $30 / 09 / 2008$ & $30 / 09 / 2008-16 / 11 / 2008$ & 47 & $46(98)$ & 88 & $\mathrm{~F}$ & 1289 \\
\hline $344(7)$ & $30 / 09 / 2008$ & $30 / 09 / 2008-16 / 11 / 2008$ & 47 & $45(96)$ & 110 & $\mathrm{~F}$ & 1019 \\
\hline $345(2)^{\mathrm{a}}$ & $30 / 09 / 2008$ & na & na & 3 & 83 & $\mathrm{~F}$ & 59 \\
\hline $348(11)^{\mathrm{a}}$ & $01 / 10 / 2008$ & na & na & 32 & 83 & $\mathrm{~F}$ & 773 \\
\hline 249 (12) & $01 / 10 / 2008$ & 01/10/2008-16/11/2008 & 46 & 41 (89) & 70 & M & 415 \\
\hline $365(5)^{a}$ & 01/10/2008 & na & na & 22 & 90 & M & 397 \\
\hline $488(4)^{\mathrm{a}}$ & $01 / 10 / 2008$ & na & na & 27 & 84 & M & 913 \\
\hline $555(1)^{\mathrm{a}}$ & $01 / 10 / 2008$ & na & na & 35 & 82 & M & 1233 \\
\hline $677(9)$ & $01 / 10 / 2008$ & 01/10/2008-16/11/2008 & 46 & $13(28)$ & 97 & M & 132 \\
\hline $678(10)$ & 01/10/2008 & 01/10/2008-16/11/2008 & 46 & 41 (89) & 80 & $\mathrm{~F}$ & 805 \\
\hline $377(6)$ & $01 / 10 / 2008$ & 01/10/2008-16/11/2008 & 46 & $42(91)$ & 63 & $\mathrm{~F}$ & 1442 \\
\hline $376(13)$ & 02/10/2008 & $02 / 10 / 2008-16 / 11 / 2008$ & 45 & $14(31)$ & 92 & M & 219 \\
\hline $456(8)$ & 05/10/2008 & 05/10/2008-16/11/2008 & 42 & $41(98)$ & 109 & M & 676 \\
\hline Total & & & & & & & 9372 \\
\hline
\end{tabular}

adjusted by adding 60 min (mean time difference between NOAA estimate and 73 observed high tide times determined at AS). Tidal phases were defined by $2 \mathrm{~h}$ either side of high and low tide; points within this $4 \mathrm{~h}$ peak were considered to be at high or low tide (Wetherbee et al. 2007). 
Individual trajectories of sharks were determined by intermittent active tracking (on sub-adults tagged above) and a database of a further 43 sub-adult lemon sharks that were actively tracked from 1992 to 2005 (Appendix 1), providing further predator movement information. Briefly, all sharks (past and in this study) were tracked using a directional hydrophone (DH-4, Sonotronics ${ }^{\circledR}$ ) with a manual tracking receiver (USR-96, Sonotronics ${ }^{\circledR}$ ) from a shallow-drafted $14 \mathrm{ft}$ skiff capable of entering water $<40 \mathrm{~cm}$ deep. A Global Positioning System (GPS) was used to take a point of the tracking boat's position, along with bearing and estimated distance to the tracked shark, which were recorded every 5 to 15 min (for further details see Sundström et al. 2001 and Franks 2007). Predator density at high and low tides (from all active tracks) were then estimated by overlaying a grid (75 $\times 75 \mathrm{~m}$ cell size) on the map of each nursery and calculating a predator score that was based on the number of predator locations in each cell of the grid. Details of all sharks tracked are given in Appendix 1.

\section{Data analysis}

Prior to analysis, all data were checked for parametric assumptions and, where appropriate, log or arcsine transformed. Analyses were conducted for all time periods when replicates allowed. Over the entire study period for each shark that had been observed to use AS on $\geq 5$ occasions, we compared the average high tide depth and water temperature where individual sharks were found in AS to the average of all high tide depths and water temperatures available to them at this location (calculated by counting the number of observation days between an individual shark's first and last sighting). A matchedpair $t$-test was then used to test if greater numbers of sharks used AS at different water temperatures and depths. Linear regression models (LM function in $\mathrm{R}$ software) were used throughout the analysis for the following reasons: (1) to assess whether the observation duration was affected by high tide depth and temperature; (2) to investigate the effect of body length on mean time that individual sharks spent in AS and on the mean time to high tide from the time of exit for individual sharks from $\mathrm{AS}_{\text {; }}$ and (3) to determine whether the order of departure from the inside section of the refuge was related to body length. A standardized mean exit score, (exit rank / total number of sharks) $\times 100$, was calculated for each shark for all observation days when that individual was seen. A proportion of the possible observation days was calculated for visits made to AS (i.e. number of observation days between first and last sighting / number of days observed to use AS). All statistical analyses were carried out in $\mathrm{R}$ version 2.8.1 (R Development Core Team 2008).

\section{RESULTS}

\section{Juvenile refuge use and movement patterns}

Juvenile lemon sharks were observed to use AS on 69 of $73(94.5 \%)$ observation days. The number of sharks using AS on a daily basis ranged from 0 to 14 tagged (mean $\pm \mathrm{SD}=6 \pm 3$ sharks) and 0 to 4 untagged individuals (1 \pm 1 shark). Observation duration (defined as the total time between the first shark arriving and the last shark departing) peaked at $7.5 \mathrm{~h}$ on 1 observation d $(2.9 \pm 2.1 \mathrm{~h})$. Sharks were observed to use AS for time scales varying from $1 \mathrm{~d}$ to $2.5 \mathrm{yr}(6.2 \pm 7.2 \mathrm{mo})$. Our initial analyses indicated that significantly more juvenile lemon sharks used AS at deeper $(d)$ and warmer $(T)$ high tides (paired $t$ tests, $d: t_{21}=8.68, \mathrm{p}<0.001 ; T: t_{14}=6.03, \mathrm{p}<0.001$ ) and that the duration over which sharks were seen was significantly longer during deeper and warmer high tides (LM, $d: F_{1,51}=22.5, \mathrm{p}<0.001 ; T$ : $F_{1,51}=$ $4.14, \mathrm{p}<0.05)$. Juvenile lemon shark body length was significantly correlated with the proportion of individual shark visits made to AS (Table 3, Fig. 2a). On average, smaller sharks also exited AS last and spent significantly more time in AS than larger conspecifics (Table 3, Fig. 2b). In addition, shark total length was

Table 3. Negaprion brevirostris. Summary results for the relationship between juvenile lemon shark body length and Aya's Spot use. See Fig. 2a-c for graphical representations of these analyses

\begin{tabular}{|lccccc|}
\hline Analysis & Time period & $F$ & $\mathrm{R}^{2}$ & $\mathrm{df}$ & $\mathrm{p}$ \\
\hline Proportion of visits & May-Dec 06 & 3.86 & 0.40 & 1,14 & 0.069 \\
& Jan-May 07 & 10.14 & 0.48 & 1,9 & 0.011 \\
& May-Dec 07 & 15.8 & 0.68 & 1,9 & 0.007 \\
Order of exit & May-Dec 06 & 13.18 & 0.54 & 1,9 & 0.005 \\
Time spent in area & May-Dec 06 & 12.1 & 0.58 & 1,7 & 0.010 \\
& Jan-May 07 & 17.7 & 0.67 & 1,7 & 0.004 \\
Mean time to high & May-Dec 06 & 23.81 & 0.62 & 1,13 & 0.000 \\
tide from exit time & May-Dec 07 & 10.11 & 0.53 & 1,7 & 0.015 \\
& & & & & \\
\hline
\end{tabular}



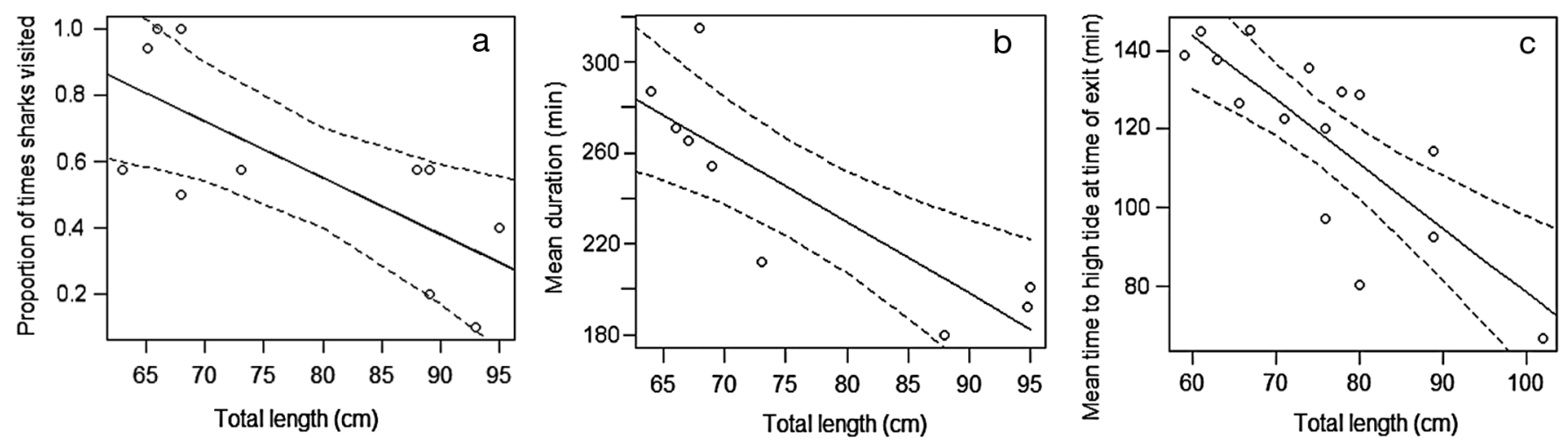

Fig. 2. Negaprion brevirostris. Linear regressions (solid lines) ( $\pm 95 \%$ confidence intervals, dashed lines) between the total length of lemon sharks and (a) the back-transformed proportion of visits made to the Aya's Spot refuge site (January to May 2007), (b) the mean duration of time spent in the Aya's Spot refuge site (January to May 2007), and (c) the mean time to high tide from the time of exit from the Aya's Spot refuge site (May to December 2006)

found to be negatively related to the mean time to high tide (following the tidal maximum) from the time sharks exited the AS site (Table 3, Fig. 2c). Finally, juvenile lemon sharks displayed a distinct and repeatable tidal pattern (Fig. 3) where over the high tide phase sharks were predominantly detected in AS or other locations close to shore, which provide shallow refuge habitat from predators, whereas during low tide they were detected at UR locations further offshore, such as Nurse Shark Channel and BFH sand flats (Fig. 4a, see Table 2 for UR detections summary).

\section{Sub-adult movement patterns}

Sub-adult lemon sharks, like juveniles, also showed tidally influenced movement patterns with greater numbers detected at sites closer to shore during the high tide, such as at URs in BFH nursery, than at low tide, such as URs east of Nurse Shark Channel in the lagoon (Fig. 4b). Our estimated predator density maps also show a clear tidal pattern with apparent density at its greatest in the BFH nursery area during high tide (Fig. 5a). At low tide, predator density decreases in the BFH nursery area with sub-

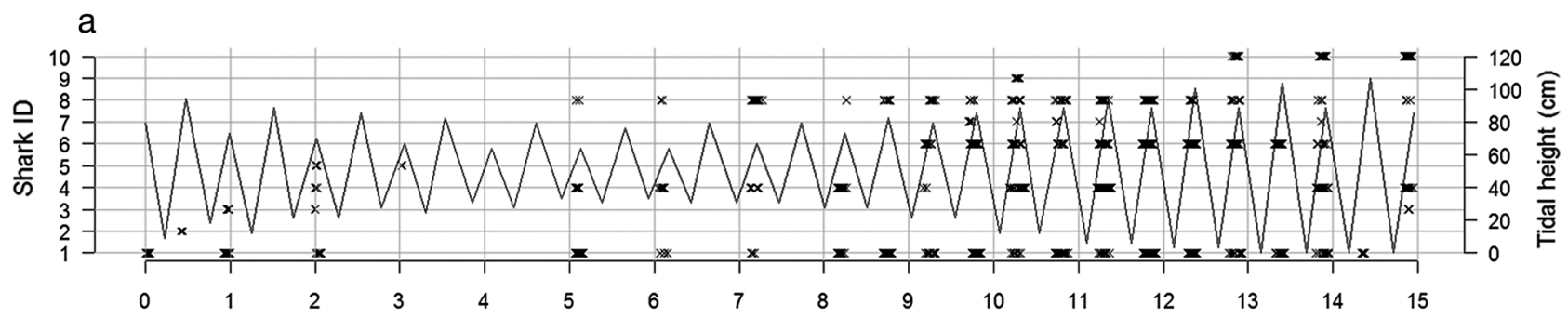

b

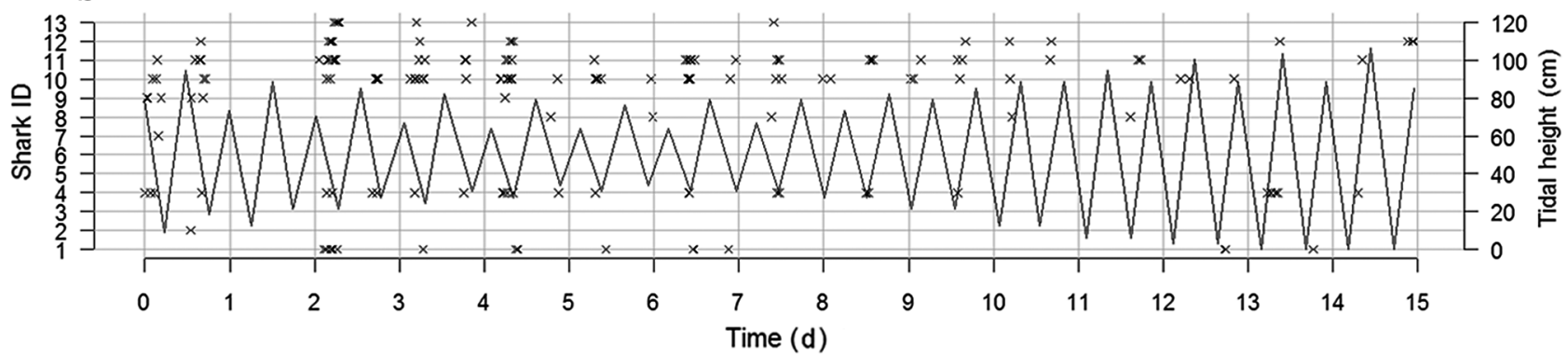

Fig. 3. Negaprion brevirostris. Acoustic signals from transmitters implanted in juvenile lemon sharks 1 to 13 in October 2008. Individual detections of each juvenile lemon shark $(x)$ in real time (Time $0=$ initial deployment of receivers) over a $15 \mathrm{~d}$ period are shown. Tidal cycle (grey line) with the peaks indicating high tides and troughs low tides. The presence of sharks during different tidal cycles are shown for 2 locations: (a) Aya's Spot, the back of a mangrove lake, where the majority of detections occurred during high tide; and (b) Nurse Shark Channel, a small pool area on lagoon sand flats in Bone Fish Hole where the majority of detections occurred during the low tide. See Table 2 for summary 


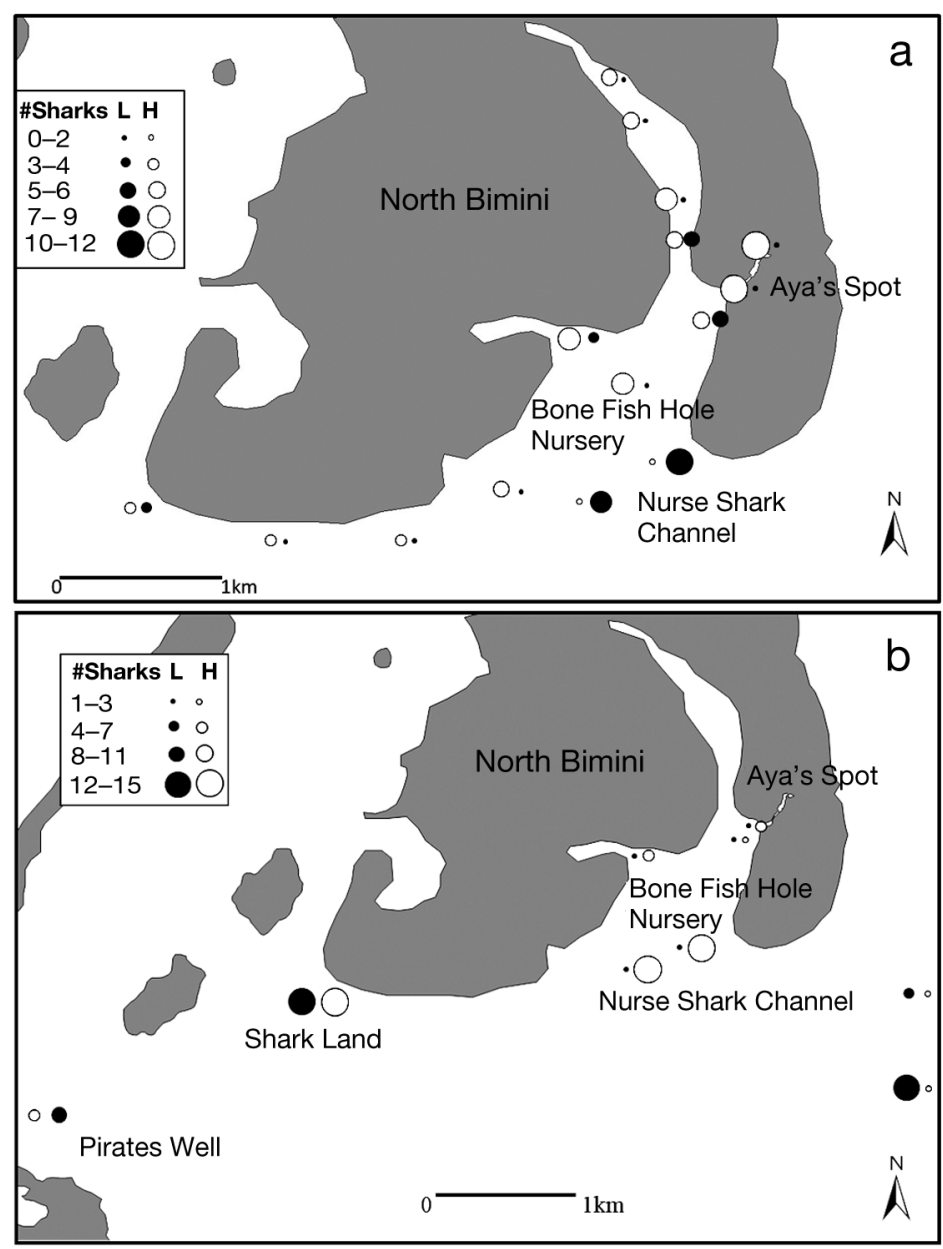

Fig. 4. Negaprion brevirostris. The number of (a) juvenile and (b) subadult lemon sharks detected at low $(\mathrm{L})$ and high $(\mathrm{H})$ tides on the underwater receivers (URs) in the Bone Fish Hole nursery area $\left(25^{\circ} 44^{\prime} \mathrm{N}\right.$, $79^{\circ} 16^{\prime}$ W). Juveniles were tracked from September to November 2008 and sub-adults from January 2007 to November 2008

adult sharks moving out of the main lagoon and using locations further offshore (Fig. 5b, see Table 1 for UR detections summary).

\section{DISCUSSION}

The results of this study suggest that juvenile lemon sharks are sensitive to tidally linked changes in predator presence and manage this risk by using shallow-water mangrove inlets, such as Aya's Spot, that are inaccessible to larger predatory sharks (subadult lemon sharks) over the high tide. In accordance with our predictions, greater numbers of juveniles were observed to use AS for longer periods when high tide depths were deeper and warmer, coincid-
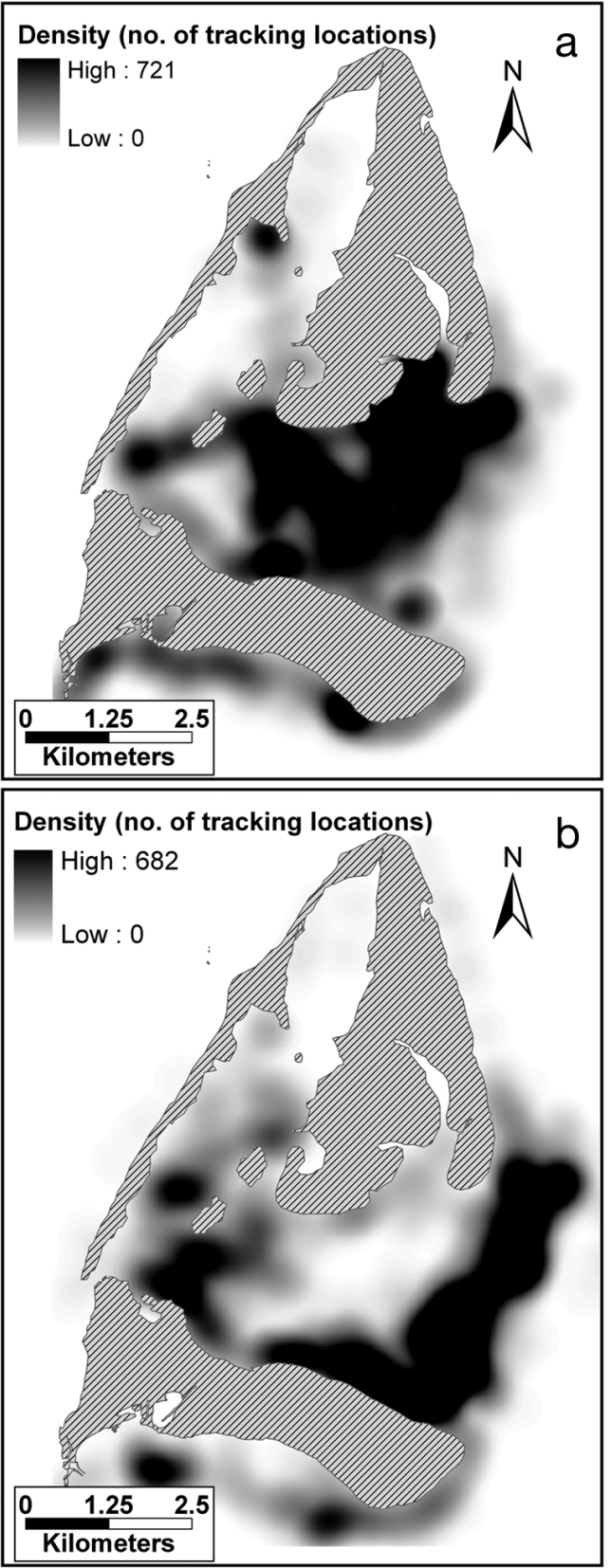

Fig. 5. Negaprion brevirostris. (a) High and (b) low tide predator-density plots of sub-adult lemon sharks in the Bimini Islands $\left(25^{\circ} 44^{\prime} \mathrm{N}, 79^{\circ} 16^{\prime} \mathrm{W}\right)$ derived from active tracking by a small vessel equipped with GPS to obtain estimated locations of each shark through time. Areas of dark grey indicate high numbers of locations and white indicates areas with low numbers. Total number of locations for high and low tide was 3789 and 3625, respectively

ing with an increased presence of potential predators (sub-adult lemon sharks) in the surrounding areas. Furthermore, as juvenile lemon sharks increase in body size their vulnerability to predators should 
decrease due to gape-limited predation capacity. As a consequence their use of refuge habitats, such as $\mathrm{AS}$, should reflect this reduction in predation risk. We found body-size dependent differences in the use of AS with smaller juvenile lemon sharks using the site at high tide for longer, making a greater number of visits to the area and departing, on average, later than larger conspecifics. Our results imply that juvenile lemon sharks were capable of making fine-scale decisions about habitat use in response to spatiotemporal changes in intra-specific predation risk. We suggest these decisions are updated throughout ontogeny and also with daily fluctuations in abiotic factors, such as depth.

The formation of predictable aggregations within the nursery habitats of juvenile sharks is not a novel observation per se (Heupel \& Simpfendorfer 2005, Papastamatiou et al. 2009). However, the interaction between abiotic conditions, such as the tidal cycle and anti-predator investment by large marine prey species, has infrequently been considered (Kerford et al. 2008). In coastal habitats, where water depth changes significantly over the tidal cycle (Sheaves 2005), the range of shallow habitats available to large-bodied predators increases over the high tide, so in response, small-bodied prey must go to even shallower locations or use different habitats that remain relatively inaccessible to avoid these predators (Manderson et al. 2004, Kerford et al. 2008). For juvenile lemon sharks in this study, a distinct and repeatable tidal pattern existed; over the high tide phase sharks aggregated in a shallow-water mangrove inlet (AS) or used other habitats close to the mangrove edge, whereas during low tide they moved out of this area and further offshore to sand flats. Tidal state has also been shown to affect shark behaviour in several locations and in a number of species (Hight \& Lowe 2007, Papastamatiou et al. 2009, Knip et al. 2010). Increased predation risk over high tide has been previously hypothesized to be driving juvenile shark space use behaviour (Wetherbee et al. 2007, Garla et al. 2009). In this study, we found that greater numbers of juveniles were observed in AS during the deepest high tide depths, with larger juveniles ( 0.9 to $1.1 \mathrm{~m}$ ) also observed more regularly at these deeper depths (T. L. Guttridge pers. obs.). If predation risk was an important mechanism driving such habitat selection, then we would expect predation pressure to increase when water depth becomes deeper in the juveniles' core habitat. Sub-adult lemon sharks in the study area are recognised predators of juvenile lemon sharks (Morrissey \& Gruber 1993). Extensive active and passive tracking, prior to and during the present study, of these sharks show similar depth- and tidally-influenced movements, with sub-adult lemon sharks selecting habitats closer to shore at deeper depths, i.e over the high tide of a tidal cycle (Sundström et al. 2001). Our predator density plots and detections by underwater acoustic receivers during high and low tides corroborate these findings, showing that sub-adult lemon sharks do access areas closer to shore and use the mangroves over high tide but access them infrequently over the low tide phase; however, due to the variability in our UR detection ranges at different depths, we cannot conclusively say that transmitter-carrying sub-adult predators were not present at low tide. Historical evidence from active tracking and recent aerial surveys supports our findings (Sundström et al. 2001, Kessel 2010). Furthermore, simultaneous to this study, direct observations (23 over low tide and 12 over high tide) were made from a tower positioned at the end of Nurse Shark Channel in BFH. No juvenile lemon sharks ( $<1.1 \mathrm{~m} \mathrm{TL})$ were observed over the high tide, whereas 13 sub-adult lemon sharks ( $>1.3 \mathrm{~m} \mathrm{TL}$ ) were recorded. In contrast, over the low tide phase no lemon sharks $>1.1 \mathrm{~m}$ TL were present and 10 juveniles that were tagged in AS, along with numerous untagged juveniles, were observed (Guttridge 2009). Finally, on 2 occasions large lemon sharks $(>2.0 \mathrm{~m})$ were observed to patrol the area in front of Tower 1 at high tide. In both instances, juveniles in the area displayed strong flight responses, seeking cover in the back section of the AS site, where a shallow water channel $(<0.8 \mathrm{~m})$ and mangrove prop roots prevent large sharks from entering.

In many animal taxa, the risk of predation has been shown to decline dramatically as body size increases and size-limited predation can induce ontogenetic niche shifts (Werner \& Gilliam 1984, Kramer et al. 1997, Brose et al. 2006). For elasmobranchs, ontogenetic shifts have been previously acknowledged in relation to diet and activity space; however, few studies have investigated ontogenetic differences in anti-predator investment, such as the use of refuges (Grubbs 2010). Our results are consistent with such trends, with smaller juvenile lemon sharks visiting AS more often, spending longer there and on average departing later. Alternatively, the observed body-size dependent use of AS could be related to ontogenetic shifts in diet (Newman et al. 2010) or larger juveniles needing to depart later due to depth restricting use. However, we consider these explanations unlikely because juvenile lemon sharks were regularly observed swimming in water with their dorsal fins exposed 
(Morrissey \& Gruber 1993) and very infrequently foraging in AS.

We acknowledge that while tidally-influenced changes in predation risk by sub-adult lemon sharks appear to be responsible for the observed habitat selection of juvenile lemon sharks, other factors may have contributed, such as other predators being present in the study system, spatially-driven feeding opportunities, or behavioural thermoregulation (Knip et al. 2010, Speed et al. 2010). A recent long-line study revealed that large predatory sharks, such as tiger and bull sharks, are present in Bimini (Kessel 2010). Although these species have never been caught and are rarely observed in the BFH nursery area, their presence suggests that predation risk from these larger sharks might also be driving the high tide habitat selection of the juvenile lemon sharks, as well as that of the sub-adult lemon sharks (Kessel 2010). For other juvenile sharks and for the sharks in this study, the use of high tide microhabitats could be related to the increased availability of preferred food instead of predator avoidance (Heupel \& Simpfendorfer 2005, Papastamatiou et al. 2009). Prey communities within mangrove habitats show distinct movements with the tidal cycle (Sheaves 2005, Valentine-Rose et al. 2007) and juvenile lemon shark movements could be linked with these tidally-driven prey migrations. A recent study in Andros, Bahamas, documented higher relative predation risk at deeper high tide depths for an abundant fish taxon, the mojarra Eucinostomus spp. (Rypel et al. 2007). Prey preference and dietary analysis of juvenile lemon sharks in Bimini show high overlap with mangrove prey communities, and yellowfin mojarra Gerres cinereus dominates their diet (Newman et al. 2010). However, despite this evidence over the 73 observation days conducted during our study, only a single predation event between a juvenile lemon shark and its prey was observed at the AS refuge site, and very few searching, chasing or hunting events were recorded. This suggests that the diurnal use of AS was not due principally to increased feeding opportunities. In contrast, during 12 of 23 low tide direct observations conducted in Nurse Shark Channel, multiple juvenile lemon sharks were recorded foraging (chasing and digging), and on 4 occasions, predation events were observed (Guttridge 2009).

We also found that greater numbers of juvenile lemon sharks spent more time at the AS refuge site during warmer temperatures. Physiological functions are directly affected by changes in temperature (Schmidt-Nielsen 1990), and behavioural thermoregulation has been suggested for a number of elasmo- branchs (Grubbs 2010, Speed et al. 2010). For the sharks in this study, utilising warmer water would likely increase rates of metabolism and digestion, which in turn could lead to an increase in growth rate. However, this would also require sharks to increase their food intake due to increased activity and evacuation rates of prey items from the stomach. When the sharks were using the aggregation site their activity levels were visibly low, with periods of resting on the substrate and slow swimming speeds (T. L. Guttridge pers. obs.). Additionally, foraging behaviours were almost absent, suggesting that being in warmer water may present the juvenile sharks with an energetic disadvantage. With this in mind future work should consider a multivariate analysis that compares the strength of temperature versus tidal height effects so that physiological- and predation-risk effects can be disentangled more clearly (Wirsing et al. 2007). Behavioural decisions made by animals are dynamic involving interplay between both abiotic and biotic factors (Dill 1987, Lima \& Dill 1990). Therefore, the use of AS likely serves a dual function for juvenile lemon sharks, providing shallow, cryptic habitat to avoid predators over the high tide in combination with warm temperatures that enhance physiological function.

In conclusion, our results suggest an underlying relationship between juvenile lemon shark habitat use, body size and predation risk. Juvenile lemon sharks were capable of making fine-scale decisions about habitat use in response to spatio-temporal changes in intra-specific predation risk, which were updated through ontogeny and with daily fluctuations in abiotic factors such as depth. These findings are consistent with recent studies that have stressed the importance of top-down processes imposed by predators that influence ecosystem function and community organisation (Heithaus et al. 2008, Baum \& Worm 2009).

Acknowledgements. T.L.G. was supported by a Leverhulme study abroad studentship. We thank the volunteers and staff at the Bimini Biological Field Station for their contribution. The study was financially supported by the Bimini Biological Field Station, Lacy Hoover, Earthwatch Institute, National Science Foundation (NSF-OCE 97-12793), NERC (NE/ D011035/1) and State of Florida Department of Education (FLORIDA 8749703000001). D.W.S. was supported by the NERC Oceans 2025 Strategic Research Programme (Theme 6: Science for sustainable marine resources). We also acknowledge S. Caviezel, A. Harry, J. DeMarignac and F. Sundström for their contribution to the tracking data set and anonymous referees for their helpful comments. This research was carried out under a permit from the Department of Fisheries of the Commonwealth of the Bahamas. 


\section{LITERATURE CITED}

Abrams PA (1995) Implications of dynamically variable traits for identifying, classifying, and measuring direct and indirect effects in ecological communities. Am Nat 146: 112-134

Andrewartha HG, Birch LC (1954) The distribution and abundance of animals. University of Chicago Press, Chicago, IL

Baum JK, Worm B (2009) Cascading top-down effects of changing oceanic predator abundances. J Anim Ecol 78: 699-714

Benoit HP, McCauley E, Post JR (1998) Testing the demographic consequences of cannibalism in Tribolium confusum. Ecology 79:2839-2851

Brose U, Jonsson T, Berlow EL, Warren P and others (2006) Consumer-resource body-size relationships in natural food webs. Ecology 87:2411-2417

Chapman DD, Babcock EA, Gruber SH, DiBattista JD and others (2009) Long-term natal site-fidelity by immature lemon sharks (Negaprion brevirostris) at a subtropical island. Mol Ecol 18:3500-3507

Compagno LJV (1984) FAO species catalogue, Vol. 4. Sharks of the world: an annotated and illustrated catalogue of shark species known to date. Part 2: Carcharhiniformes. Food and Agriculture Organization of the United Nations, Rome

> Creel S, Christianson D (2008) Relationships between direct predation and risk effects. Trends Ecol Evol 23:194-201

de Marignac JR (2000) Home range and diel movement patterns of subadult lemon sharks, Negaprion brevirostris, in a shallow tropical lagoon, Bimini, Bahamas. MS thesis, San Jose State University, San Jose, CA

Dill LM (1987) Animal decision making and its ecological consequences: the future of aquatic ecology and behavior. Can J Zool 65:803-811

Dill LM, Heithaus MR, Walters CJ (2003) Behaviorally mediated indirect interactions in marine communities and their conservation implications. Ecology 84:1151-1157

Economakis AE, Lobel PS (1998) Aggregation behavior of the grey reef shark, Carcharhinus amblyrhychos, at Johnston Atoll, Central Pacific Ocean. Environ Biol Fishes 51:129-139

Feldheim KA, Gruber SH, Ashley MV (2002) The breeding biology of lemon sharks at a tropical nursery lagoon. Proc R Soc Lond B Biol Sci 269:1655-1661

Ferretti F, Worm B, Britten GL, Heithaus MR, Lotze HK (2010) Patterns and ecosystem consequences of shark declines in the ocean. Ecol Lett 13:1055-1071

Franks B (2007) The spatial ecology and resource selection of juvenile lemon sharks Negaprion brevirostris in their primary nursery areas. PhD thesis, Drexel University, Philadelphia, PA

Garla RC, Garcia J, Veras LB, Lopes NP (2009) Fernando de Noronha as an insular nursery area for lemon sharks, Negaprion brevirostris, and nurse sharks, Ginglymostoma cirratum, in the equatorial western Atlantic Ocean. Mar Biodiversity Rec 2:e109

Grubbs RD (2010) Ontogenetic shifts in movements and habitat use. In: Carrier JC, Musick JA, Heithaus MR (eds) Sharks and their relatives II: biodiversity, adaptative physiology and conservation. CRC Press, Boca Raton, FL, p 319-350

Guttridge TL (2009) The social organisation and behaviour of the juvenile lemon shark, Negaprion brevirostris. PhD thesis, University of Leeds

> Guttridge TL, Gruber SH, Krause J, Sims DW (2010) Novel acoustic technology for studying free-ranging shark social behaviour by recording individuals' interactions. PLoS ONE 5:e9324

Guttridge TL, Gruber SH, DiBattista JD, Feldheim KA, Croft DP, Krause S, Krause J (2011) Assortative interactions and leadership in a free-ranging population of juvenile lemon shark Negaprion brevirostris. Mar Ecol Prog Ser 423:235-245

Halpin PM (2000) Habitat use by an intertidal salt-marsh fish: trade-offs between predation and growth. Mar Ecol Prog Ser 198:203-214

Heithaus MR (2007) Nursery areas as essential shark habitats: a theoretical perspective. In: McCandless CT, Kohler NE, Pratt HL (eds) Shark nursery grounds of the Gulf of Mexico and the East Coast waters of the United States. American Fisheries Society, Bethesda, MD, p 3-13

Heithaus MR, Frid A, Wirsing AJ, Worm B (2008) Predicting ecological consequences of marine top predator declines. Trends Ecol Evol 23:202-210

- Heupel MR, Simpfendorfer CA (2005) Quantitative analysis of aggregation behaviour in juvenile blacktip sharks. Mar Biol 147:1239-1249

> Hight BV, Lowe CG (2007) Elevated body temperatures of adult female leopard sharks, Triakis semifasciata, while aggregating in shallow nearshore embayments: evidence for behavioral thermoregulation? J Exp Mar Biol Ecol 352:114-128

Jackson DA, Peres-Neto PR, Olden JD (2001) What controls who is where in freshwater fish communities - the roles of biotic, abiotic, and spatial factors. Can J Fish Aquat Sci 58:157-170

Kerford MR, Wirsing AJ, Heithaus MR, Dill LM (2008) Danger on the rise: diurnal tidal state mediates an exchange of food for safety by the bar-bellied sea snake Hydrophis elegans. Mar Ecol Prog Ser 358:289-294

Kessel ST (2010) An investigation into the behaviour and population dynamics of the lemon shark (Negaprion brevirostris). PhD thesis, Cardiff University

Knip DM, Heupel MR, Simpfendorfer CA (2010) Sharks in nearshore environments: models, importance and consequences. Mar Ecol Prog Ser 402:1-11

Kohler NE, Turner PA (2001) Shark tagging: a review of conventional methods and studies. Environ Biol Fishes 60: 191-224

Kramer DL, Rangeley RW, Chapman LJ (1997) Habitat selection: patterns of spatial distribution from behavioural decisions. In: Godin JGJ (ed) Behavioural ecology of teleost fishes, Oxford University Press, New York, NY, p 37-90

Lima SL (1998) Non-lethal effects in the ecology of predator-prey interactions. BioScience 48:25-34

Lima SL (2009) Predators and the breeding bird: behavioral and reproductive flexibility under the risk of predation. Biol Rev Camb Philos Soc 84:485-513

Lima SL, Dill LM (1990) Behavioural decisions made under the risk of predation: a review and prospectus. Can J Zool 68:619-640

> Linehan JE, Gregory RS, Schneider DC (2001) Predation risk of age-0 cod (Gadus) relative to depth and substrate in coastal waters. J Exp Mar Biol Ecol 263:25-44

> Manderson JP, Pessutti J, Hilbert JG, Juanes F (2004) Shallow water predation risk for a juvenile flatfish (winter flounder; Pseudopleuronectes americanus, Walbaum) in 
a northwest Atlantic estuary. J Exp Mar Biol Ecol 304: $137-157$

Morrissey JF, Gruber SH (1993) Home range of juvenile lemon sharks, Negaprion brevirostris. Copeia 425-434

> Newman SP, Handy RD, Gruber SH (2010) Diet and prey preference of juvenile lemon sharks Negaprion brevirostris. Mar Ecol Prog Ser 398:221-234

Nilsson PA, Brönmark C, Pettersson LB (1995) Benefits of a predator-induced morphology in crucian carp. Oecologia 104:291-296

Papastamatiou YP, Lowe CG, Caselle JE, Friedlander AM (2009) Scale-dependent effects of habitat on movements and path structure of reef sharks at a predator-dominated atoll. Ecology 90:996-1008

Pillans RD, Franklin CE (2004) Plasma osmolyte concentrations and rectal gland mass of bull sharks Carcharhinus leucas, captured along a salinity gradient. Comp Biochem Physiol A 138:363-371

R Development Core Team (2008) R: a language and environment for statistical computing. R Foundation for Statistical Computing, Vienna. www.r-project.org

Rypel AL, Layman CA, Arrington DA (2007) Water depth modifies relative predation risk for a motile fish taxon in Bahamian tidal creeks. Estuar Coasts 30:518-525

Schmidt-Nielsen K (1990) Animal physiology: adaptation and environment, 4th edn. Cambridge University Press, Cambridge

Sheaves M (2005) Nature and consequences of biological connectivity in mangrove systems. Mar Ecol Prog Ser 302:293-305

Sheppard JK, Jones RE, Marsh H, Lawler IR (2009) Effects of tidal and diel cycles on dugong habitat use. J Wildl Manage 73:45-59

Snelson FF, Mulligan TJ, Williams SE (1984) Food habits, occurrence and population structure of the bull shark, Carcharhinus leucas, in Florida coastal lagoons. Bull Mar Sci 34:71-80

Speed CW, Field IC, Meekan MG, Bradshaw CJA (2010) Complexities of coastal shark movements and their impli- cations for management. Mar Ecol Prog Ser 408:275-293

> Sundström LF, Gruber SH, Clermont SM, Correia JPS, and others (2001) Review of elasmobranch behavioural studies using ultrasonic telemetry with special reference to the lemon shark, Negaprion brevirostris, around Bimini Islands, Bahamas. Environ Biol Fishes 60:225-250

> Trussell GC, Ewanchuk PJ, Bertness MD, Silliman BR (2004) Trophic cascades in rocky shore tide pools: distinguishing lethal and nonlethal effects. Oecologia 139:427-432

Valentine-Rose L, Layman CA, Arrington DA, Rypel AL (2007) Habitat fragmentation decreases fish secondary production in Bahamian tidal creeks. Bull Mar Sci 80: 863-877

- Van Buskirk J, Arioli M (2002) Dosage response of an induced defense: How sensitive are tadpoles to predation risk? Ecology 83:1580-1585

> Vorenberg MM (1962) Cannibalistic tendencies of lemon and bull sharks. Copeia 1962:455-456

Werner EE, Gilliam JF (1984) The ontogenetic niche and species interactions in size-structured populations. Annu Rev Ecol Syst 15:393-425

> Werner EE, Peacor SD (2006) Lethal and nonlethal predator effects on an herbivore guild mediated by system productivity. Ecology 87:347-361

- Wetherbee BM, Gruber SH, Rosa RS (2007) Movement patterns of juvenile lemon sharks Negaprion brevirostris within Atol das Rocas, Brazil: a nursery characterized by tidal extremes. Mar Ecol Prog Ser 343:283-293

Wirsing AJ, Heithaus MR, Dill LM (2007) Fear factor: Do dugongs (Dugong dugon) trade food for safety from tiger sharks (Galeocerdo cuvier)? Oecologia 153:1031-1040

> Wirsing AJ, Heithaus MR, Frid A, Dill LM (2008) Seascapes of fear: evaluating sublethal predator effects experienced and generated by marine mammals. Mar Mamm Sci 24:1-15

- Wissinger SA, Whiteman HH, Denoël M, Mumford LM, Aubee CB (2010) Consumptive and nonconsumptive effects of cannibalism in fluctuating age-structured populations. Ecology 91:549-559 
Appendix 1. Negaprion brevirostris. Summary of all sub-adult lemon shark active tracks used in this study to determine predation risk. Data used were from researchers over the 1992-2008 period. M: male, F: female

\begin{tabular}{|c|c|c|c|c|c|c|}
\hline $\begin{array}{l}\text { Shark ID } \\
\text { code }\end{array}$ & $\begin{array}{c}\text { Date tagged } \\
\text { (d/mo/yr) }\end{array}$ & $\begin{array}{l}\text { Total length } \\
\text { (cm) }\end{array}$ & Sex & $\begin{array}{l}\text { No. of } \\
\text { fixes }\end{array}$ & $\begin{array}{l}\text { Total time } \\
\text { tracked (h) }\end{array}$ & Source \\
\hline AND & 03/11/92 & 182 & $\mathrm{~F}$ & 226 & 56.5 & DeMarignac (2000) \\
\hline MAT & 03/11/92 & 190 & M & 83 & 20.8 & DeMarignac (2000) \\
\hline PIC & $12 / 11 / 92$ & 144 & M & 89 & 22.3 & DeMarignac (2000) \\
\hline ENI & $13 / 11 / 92$ & 183 & M & 50 & 12.5 & DeMarignac (2000) \\
\hline LIS & $13 / 11 / 92$ & 156 & $\mathrm{~F}$ & 180 & 45 & DeMarignac (2000) \\
\hline YOL & $13 / 11 / 92$ & 153 & $\mathrm{~F}$ & 43 & 10.8 & DeMarignac (2000) \\
\hline CAP & $20 / 02 / 93$ & 160 & $\mathrm{~F}$ & 481 & 120.3 & DeMarignac (2000) \\
\hline NAN & $21 / 02 / 93$ & 156 & M & 265 & 66.3 & DeMarignac (2000) \\
\hline ZEL & $21 / 02 / 93$ & 166 & $\mathrm{~F}$ & 47 & 11.8 & DeMarignac (2000) \\
\hline GON & $22 / 02 / 93$ & 150 & M & 50 & 12.5 & DeMarignac (2000) \\
\hline SEB & $22 / 02 / 93$ & 164 & M & 33 & 8.3 & DeMarignac (2000) \\
\hline BAC & $19 / 01 / 94$ & 151 & M & 658 & 164.5 & DeMarignac (2000) \\
\hline URS & $21 / 01 / 94$ & 173 & $\mathrm{~F}$ & 396 & 99 & DeMarignac (2000) \\
\hline JUN & $24 / 01 / 94$ & 169 & M & 80 & 20 & DeMarignac (2000) \\
\hline TOO & $25 / 01 / 94$ & 186 & $\mathrm{~F}$ & 529 & 132.3 & DeMarignac (2000) \\
\hline QUE & $16 / 06 / 94$ & 176 & $\mathrm{~F}$ & 736 & 184 & DeMarignac (2000) \\
\hline DAM & $17 / 06 / 94$ & 162 & M & 492 & 123 & DeMarignac (2000) \\
\hline ROX & 18/06/94 & 155 & $\mathrm{~F}$ & 600 & 150 & DeMarignac (2000) \\
\hline WAG & $19 / 06 / 94$ & 161 & $\mathrm{~F}$ & 1172 & 293 & DeMarignac (2000) \\
\hline IAG & $21 / 06 / 94$ & 158 & M & 397 & 99.3 & DeMarignac (2000) \\
\hline OJ & $21 / 06 / 94$ & 198 & M & 286 & 71.5 & DeMarignac (2000) \\
\hline FOX & $03 / 08 / 94$ & 150 & $\mathrm{~F}$ & 132 & 33 & DeMarignac (2000) \\
\hline KRU & $25 / 08 / 94$ & 196 & $\mathrm{M}$ & 379 & 94.8 & DeMarignac (2000) \\
\hline HOM & $28 / 08 / 94$ & 167 & M & 19 & 4.8 & DeMarignac (2000) \\
\hline XLA & $29 / 08 / 94$ & 161 & $\mathrm{~F}$ & 409 & 102.3 & DeMarignac (2000) \\
\hline DRG & $22 / 01 / 95$ & 156 & M & 1465 & 366.3 & DeMarignac (2000) \\
\hline VER & $22 / 01 / 95$ & 166 & $\mathrm{~F}$ & 1160 & 290 & DeMarignac (2000) \\
\hline PRI & $10 / 04 / 95$ & 195 & M & 1328 & 332 & DeMarignac (2000) \\
\hline 124 & $29 / 01 / 96$ & 154 & $\mathrm{~F}$ & 680 & 56.7 & Sundström et al. (2001) \\
\hline 115 & $26 / 02 / 96$ & 188 & M & 246 & 20.5 & Sundström et al. (2001) \\
\hline 97 & $15 / 03 / 96$ & 170 & $\mathrm{~F}$ & 876 & 73 & Sundström et al. (2001) \\
\hline $339 A$ & $09 / 03 / 97$ & 166 & M & 633 & 52.8 & Sundström et al. (2001) \\
\hline 339B & 08/05/97 & 167 & M & 692 & 57.7 & Sundström et al. (2001) \\
\hline $348 B$ & $27 / 06 / 97$ & 164 & $\mathrm{~F}$ & 894 & 74.5 & Sundström et al. (2001) \\
\hline $348 \mathrm{~A}$ & 07/07/97 & 160 & $\mathrm{~F}$ & 531 & 44.3 & Sundström et al. (2001) \\
\hline $348 \mathrm{C}$ & $27 / 07 / 97$ & 174 & $\mathrm{~F}$ & 1008 & 84 & Sundström et al. (2001) \\
\hline $267 \mathrm{~B}$ & 08/08/97 & 180 & M & 945 & 78.8 & Sundström et al. (2001) \\
\hline $267 \mathrm{~A}$ & $22 / 08 / 97$ & 183 & M & 545 & 45.4 & Sundström et al. (2001) \\
\hline 354 & $26 / 11 / 03$ & 129 & M & 537 & 44.8 & Franks (2007) \\
\hline 374 & $27 / 01 / 04$ & 119 & $\mathrm{~F}$ & 492 & 41 & Franks (2007) \\
\hline 365 & $08 / 07 / 04$ & 116 & $\mathrm{~F}$ & 148 & 12.3 & Franks (2007) \\
\hline 446 & 05/05/05 & 124 & M & 501 & 41.8 & Franks (2007) \\
\hline 234 & 06/07/05 & 125 & $\mathrm{M}$ & 338 & 28.2 & Franks (2007) \\
\hline 222 & $31 / 07 / 05$ & 146 & $\mathrm{M}$ & 211 & 17.6 & Franks (2007) \\
\hline 3775 & $31 / 10 / 06$ & 145 & $\mathrm{~F}$ & 75 & 6.3 & T. L. Guttridge \& S. T. Kessel (unpubl. data) \\
\hline 3774 & $11 / 12 / 06$ & 163 & M & 201 & 16.8 & T. L. Guttridge \& S. T. Kessel (unpubl. data) \\
\hline 4467 & 03/01/07 & 157 & $\mathrm{~F}$ & 178 & 14.8 & T. L. Guttridge \& S. T. Kessel (unpubl. data) \\
\hline 4568 & $31 / 01 / 07$ & 196 & $\mathrm{~F}$ & 200 & 16.7 & T. L. Guttridge \& S. T. Kessel (unpubl. data) \\
\hline 3386 & $20 / 04 / 07$ & 167 & $\mathrm{M}$ & 35 & 2.9 & T. L. Guttridge \& S. T. Kessel (unpubl. data) \\
\hline 3475 & $20 / 04 / 07$ & 205 & $\mathrm{M}$ & 3 & 0.3 & T. L. Guttridge \& S. T. Kessel (unpubl. data) \\
\hline 3558 & 06/06/07 & 136 & $\mathrm{~F}$ & 35 & 2.9 & T. L. Guttridge \& S. T. Kessel (unpubl. data) \\
\hline 446 & $14 / 06 / 07$ & 180 & M & 52 & 4.3 & T. L. Guttridge \& S. T. Kessel (unpubl. data) \\
\hline 3354 & $14 / 06 / 07$ & 190 & M & 9 & 0.8 & T. L. Guttridge \& S. T. Kessel (unpubl. data) \\
\hline 376 & $22 / 07 / 07$ & 147 & $\mathrm{M}$ & 25 & 2.1 & T. L. Guttridge \& S. T. Kessel (unpubl. data) \\
\hline 3366 & 04/10/07 & 141 & $\mathrm{M}$ & 92 & 7.7 & T. L. Guttridge \& S. T. Kessel (unpubl. data) \\
\hline 3347 & $15 / 05 / 08$ & 145 & M & 131 & 10.9 & T. L. Guttridge \& S. T. Kessel (unpubl. data) \\
\hline 334 & 05/10/08 & 130 & M & 26 & 2.2 & T. L. Guttridge \& S. T. Kessel (unpubl. data) \\
\hline
\end{tabular}

